\title{
Extensive dentigerous cyst associated with a maxillary mesiodens in a 55-year-old male - case report and literature review
}

\section{Rozległa torbiel zawiązkowa od zęba środkowego szczęki u 55-letniego mężczyzny - opis przypadku i przegląd piśmiennictwa}

\author{
Aleksandra Rubinkiewicz' , Maciej Sikora ${ }^{2,3}$, Marcin Sielski1 ${ }^{1,2}$, Agata Stąpor², Dariusz Chlubek ${ }^{3 凶}$ \\ ${ }^{1}$ Samodzielny Publiczny Zakład Opieki Zdrowotnej Ministerstwa Spraw Wewnętrznych i Administracji, Poradnia Chirurgii Stomatologicznej, \\ ul. Wojska Polskiego 51, 25-375 Kielce \\ Hospital of the Ministry of Interior, Outpatient Dental Surgery Center \\ ${ }^{2}$ Samodzielny Publiczny Zakład Opieki Zdrowotnej Ministerstwa Spraw Wewnętrznych i Administracji, Pododdział Chirurgii Szczękowo-Twarzowej, \\ ul. Wojska Polskiego 51, 25-375 Kielce \\ Hospital of the Ministry of Interior, Department of Maxillofacial Surgery \\ ${ }^{3}$ Pomorski Uniwersytet Medyczny w Szczecinie, Katedra Biochemii i Chemii Medycznej, al. Powstańców Wlkp. 72, 70-111 Szczecin \\ Pomeranian Medical University in Szczecin, Department of Biochemistry and Medical Chemistry \\ $\checkmark$ dchlubek@pum.edu.pl
}

\begin{abstract}
Supernumerary teeth as mesiodentes in adults are a rare condition. Given that mesiodentes often interfere with the eruption of normal permanent incisors, the majority are diagnosed in teenagers. In some cases, this pathology is associated with the presence of a dentigerous cyst. Imaging techniques play a significant role in the diagnosis of cysts, particularly cone beam computed tomography (CBCT). Once the correct diagnosis is established, appropriate therapeutic measures - usually surgical - should be initiated promptly.
\end{abstract}

The case presented here is that of a 55-year-old male with an extensive dentigerous cyst arising from a maxillary mesiodens. The decision was made to perform enucleation of the cyst along with the mesiodens inside it. The procedure was performed under general anesthesia. No complications were observed in the postoperative period. The histopathology report confirmed a dentigerous cyst. Radiograph images obtained 10 months postsurgery showed spontaneous bone tissue reconstruction. Keywords: mesiodens; dentigerous cyst; cone beam computed tomography; surgical treatment.

\begin{abstract}
ABSTRAKT
Zęby nadliczbowe w postaci mezjodensów u osób dorosłych są schorzeniem występującym rzadko. Z uwagi na fakt, że zęby środkowe często utrudniają wyrzynanie się prawidłowych stałych zębów siecznych, większość przypadków diagnozowana jest u nastolatków. Czasami patologia ta związana jest z obecnością torbieli zawiązkowej. W rozpoznaniu istotną rolę odgrywa diagnostyka obrazowa ze wskazaniem na komputerową tomografię wiązki stożkowej (CBCT). Po właściwym ustaleniu diagnozy niezbędne jest szybkie wdrożenie odpowiedniego postępowania terapeutycznego - zazwyczaj chirurgicznego.
\end{abstract}

W pracy przedstawiono przypadek 55-letniego mężczyzny z rozległą torbielą zawiązkową od zęba środkowego szczęki. Zdecydowano się na wyłu szczenie torbieli wraz z tkwiącym w niej mezjodensem. Zabieg wykonano w znieczuleniu ogólnym. Nie odnotowano u chorego powikłań w okresie pooperacyjnym. W badaniu histopatologicznym potwierdzono rozpoznanie torbieli zawiązkowej. Na obrazie rentgenowskim wykonanym po 10 miesiącach od zabiegu zaobserwowano spontaniczną odbudowę tkanki kostnej.

Słowa kluczowe: ząb środkowy; torbiel zawiązkowa; tomografia komputerowa wiązki stożkowej; leczenie chirurgiczne.

\section{INTRODUCTION}

Mesiodens is a supernumerary tooth located in the mesial line of the body between the maxillary incisors or, less frequently, between mandibular incisors. It is one of the most common types of supernumerary teeth among both deciduous and permanent teeth [1]. According to various researchers, mesiodentes account for $44-67 \%$ of all cases of hyperdontia $[2,3]$. The incidence of mesiodentes in the population varies between $0.15 \%$ and $2.2 \%[2,4,5,6]$. Amini et al., analyzing the incidence of hyperdontia in 3374 patients treated orthodontically between the ages of 10-20 years, stated that mesiodens was the most common supernumerary tooth observed [7]. According to the literature review by Meighani and Pakdaman, this pathology occurs in $0.05-0.64 \%$ of all deciduous teeth and in $0.15-3.8 \%$ of permanent teeth [5]. In the vast majority of cases, mesiodentes are found in children [7]. Their incidence is twice as frequent in men (boys) as in women (girls) $[2,3,5,8,9]$. They are located approximately 8-10 times more frequently in the maxilla than in the mandible [10]. According to the majority of 
authors, mesiodentes occur mainly in the anterior part of the jaw $[1,2,3,5,8,10,11]$. They may be single or multiple $[5,6,9,12$, 13]. As well, the majority of mesiodentes are located palatally in relation to the central incisors [13].

The etiology of this dental abnormality is not fully known. There are several theories about the etiology of hyperdontia: atavistic, dichotomous, vascular, and one associating this condition with increased activity of the dental lamina [9, 13]. The majority of authors believe that the occurrence of mesiodentes is associated with increased activity of the dental lamina, which results in the formation of an additional tooth bud, from which a supernumerary tooth develops $[1,3,5,9]$. Meighani and Pakdaman also point to cases where there is a family history of mesiodentes. They believe that this disorder is inherited as an autosomal dominant trait [5]. In a study by Syriac et al., the majority of mesiodentes were conical in shape, and in $68 \%$ of cases, the coronal part of the mesiodens was oriented in the direction consistent with normal teeth, while in the remaining patients, it was oriented in the opposite position [14]. Mesiodentes are usually smaller than normal teeth [4, 5]. According to Janas et al., they may also morphologically resemble normal incisors [15]. The presence of mesiodentes often hinders the eruption of normal permanent incisors, leading to their displacement or stopping the eruption process $[1,5,9,12]$.

Mesiodens may also cause cyst formation [16], one of the most common pathological lesions of the maxillofacial area. True cysts have an epithelium-lined sac, whereas less common pseudocysts do not have the epithelial lining. Cysts may also be divided according to the origin of the epithelium constituting their lining. If cysts are associated with the process of odontogenesis, they are called odontogenic cysts [6].

Dentigerous cysts are associated with the buds of permanent teeth. This is the second most common group of jawbone cysts, after root cysts $[6,17,18]$. Dentigerous cysts occur more frequently in the mandible than in the maxilla and are usually associated with wisdom teeth [18]. They are divided into three main categories:

1) dentigerous cyst without tooth bud,

2) dentigerous cyst with partially developed tooth bud,

3) dentigerous cyst with a fully developed tooth.

Among supernumerary teeth, the occurrence of dentigerous cysts is most often associated with mesiodentes $[6,12]$. Asaumi et al., in their summary of 11 years of observations during which they examined 200 patients with mesiodentes, cysts associated with mesiodentes were found in $11 \%$ of the examined cases [19].

\section{CASE REPORT}

The 55-year-old man was treated at the Maxillofacial Surgery Unit of the Independent Public Health Care Department of the Ministry of the Interior and Administration in Kielce in February 2018. Upon admission to the hospital, he complained of pain in the anterior part of his jaw, which had lasted for about a year. He also reported recurrent inflammatory conditions in the area. For this reason, the patient had been treated several times with antibiotics by a general practitioner. Due to the recurrent nature of the complaint, the patient was sent to the Outpatient Clinic of Maxillofacial Surgery. Pantomographic $\mathrm{X}$-ray revealed the presence of an ovoid lucency of $30 \times 25 \mathrm{~mm}$ in the anterior part of the maxilla with a well-marked areola. In the middle, closer to its lower pole, there was an excess of shadow, most likely a supernumerary tooth. Teeth 12, 11, 21, 22, 23 were endodontically treated (Fig. 1). Due to the location and atypical extent of the lesion, further imaging was performed by cone beam computed tomography (CBCT). Tomography showed the presence of an oval bone lucency measuring $30 \times 25 \mathrm{~mm}$, located palatally in relation to the roots of the teeth $12,11,21,22$. At the bottom of the bone defect, in the mesial line, there was a crown of the mesiodens (Fig. 2 a, b, c).

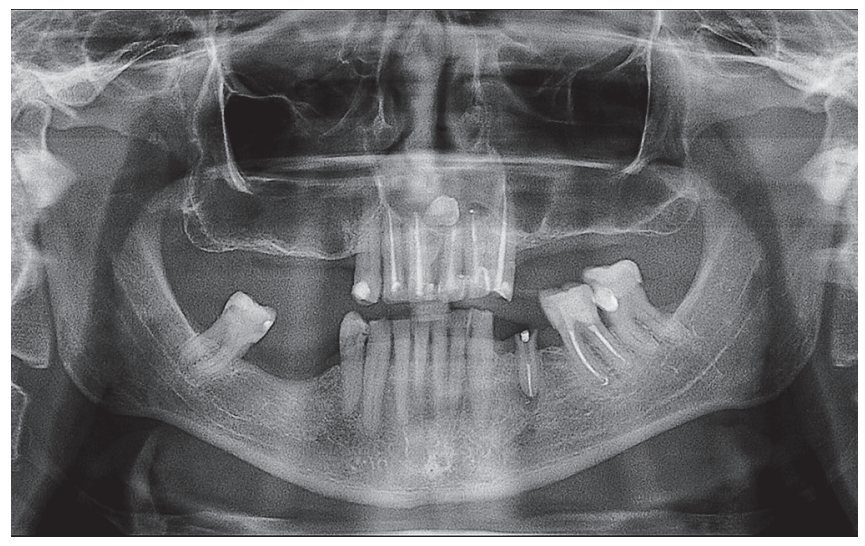

FIGURE 1. Pantomographic X-ray revealed the presence of an ovoid lucency with a well-marked areola inside of which there was a supernumerary tooth

The patient had type 2 diabetes mellitus (treated with Siofor 500 mg 0-0-1 per os) and hypercholesterolemia (treated with Lipanthyl Supra, $160 \mathrm{mg}$ 1-0-o per os). The patient reported occasional alcohol consumption and family history showed no contraindications for the surgery. No pathology was found in the clinical extraoral examination. Intraoral examination showed a slight swelling of the alveolar process in the area of teeth 12-22, particularly on the lip side, without bending or crepitus. The mucous membrane of the vestibule and the oral cavity proper was pink, smooth, shiny, and free of inflammatory features. The patient had missing teeth in the maxilla and mandible without any dentures.

After admission to the hospital, the patient underwent basic laboratory tests: peripheral blood morphology, Activated Partial Thromboplastin Time, International Normalized Ratio, and determinations of chlorides, potassium, sodium, urea, creatinine, glucose, and C-reactive protein. On the basis of clinical examination and analysis of the results of additional examinations, a preliminary diagnosis was made: a dentigerous cyst arising from the mesiodens. Two days before surgical treatment, Siofor therapy was discontinued, and insulin therapy was introduced to control glycemia. The patient was scheduled for enucleation of the cyst and the supernumerary tooth inside it, accessed through the vestibule of the oral cavity. 

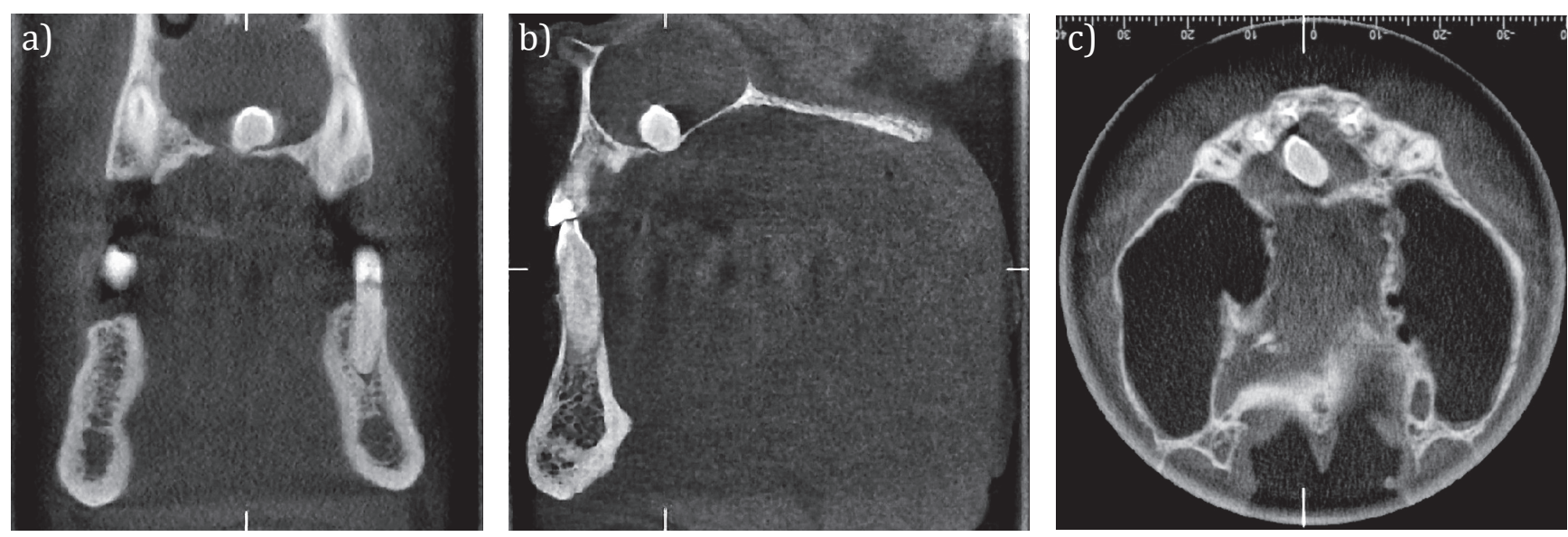

FIGURE 2 a, b, c. CBCT showed the presence of an oval bone lucency, located palatally in relation to the roots of the teeth $12,11,21,22$

On the day of the procedure, empirical antibiotic treatment with Tarsime 1.5 (1500 mg) 1-1-1 i.v., Paracetamol 1.0 (1000 mg) 1-1-1 i.v., Ketonal 0.05 (50 mg) $1 \times 1$ i.v. in case of pain, Clexane $40 \mathrm{mg} / 0.4 \mathrm{ml}$ (40 mg/0.4 ml) 1-0-1 s.c., and Gensulin R 6j-4j-4j s.c. were implemented.

Under general and local infiltration anesthesia with $2 \%$ lignocaine and noradrenaline, the anterior surface of the body of maxilla was exposed by cutting through the gingival sulcus from tooth 13 to tooth 23. The lower edge of the anterior nasal aperture was located and a bone cutter was used to cut out a window in the thinned bone covering the cyst (Fig. 3). Upon reaching the sac of the cyst, it was completely extracted together with the supernumerary tooth inside. The obtained material was sent in its entirety for histopathological examination (Fig. 4). A dense, whitish substance observed during enucleation was collected for bacteriological examination. The damaged bone lamina on the ceiling of the oral cavity produced by the cyst enucleation was removed, reaching the lumen of the maxillary sinus on the right side. Due to the vastness of the cyst, the anterior nasal spine was fractured and displaced, which was adjusted and immobilized with a Medartis foureyelet 1.5 plate fixed with two screws (Fig. 5). The wound was closed using two layer of suturing with Polysorb 4.0 and Surgipro 4.0 threads.

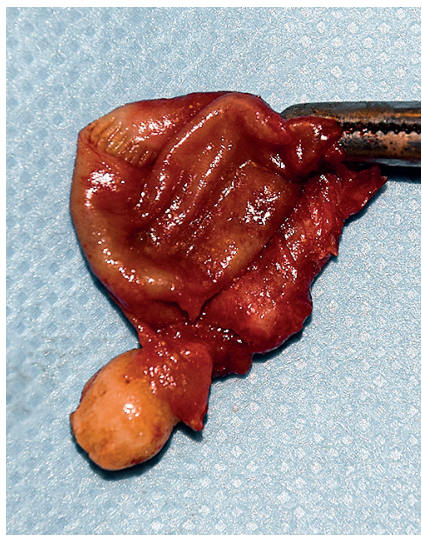

FIGURE 4. Completely extracted cyst together with the supernumerary tooth

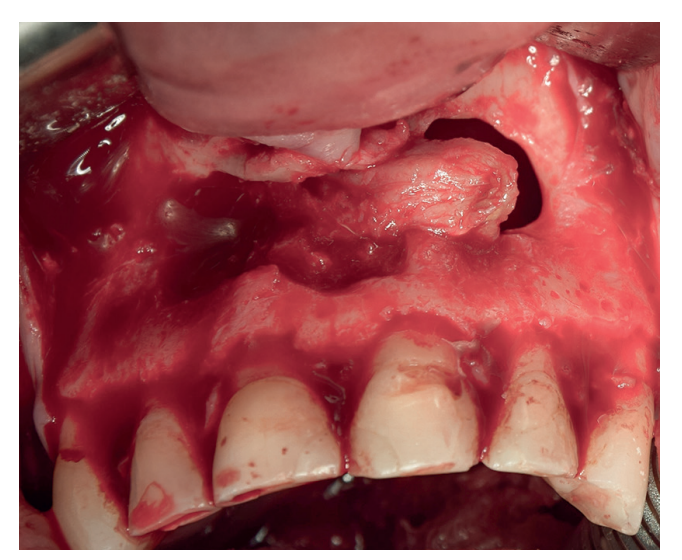

FIGURE 3. Window in the thinned bone covering the cyst

3. Window in the thinned bone covering the cyst
During the postoperative period, the patient developed moderate swelling of the operated area, though the wound healed properly. The patient was hospitalized for 3 days after surgery. Antibiotic therapy was continued, non-steroidal anti-inflammatory drugs and an oral antidiabetic drug were administered. The diet was soft and diabetic. The patient was discharged with the recommendation to continue oral antibiotic therapy (Xorimax $0.5-500 \mathrm{mg}-2 \times 1$ p.o.), practise increased oral hygiene, and return for control in 3-4 days. During the control examination, no pain, normal wound healing, and significant reduction of swelling were observed. Antibiotic treatment was discontinued. No pathogenic bacteria or yeast-like fungi were cultured from the material collected during the surgery. On the $10^{\text {th }}$ day after the procedure, the patient's stitches were removed and the intraoral wound healed properly. On the $14^{\text {th }}$ day, the result of histopathological examination was obtained, confirming the diagnosis of a dentigerous cyst.

The patient remained under observation for one year following surgery. He did not complain of any pain in the operated area, nor did he report any other problems. Proper healing of the postoperative wound was observed (Fig. 6). Ten months after surgery, pantomographic X-ray was performed, which revealed spontaneous healing of the bone defect from the cyst enucleation (Fig. 7).

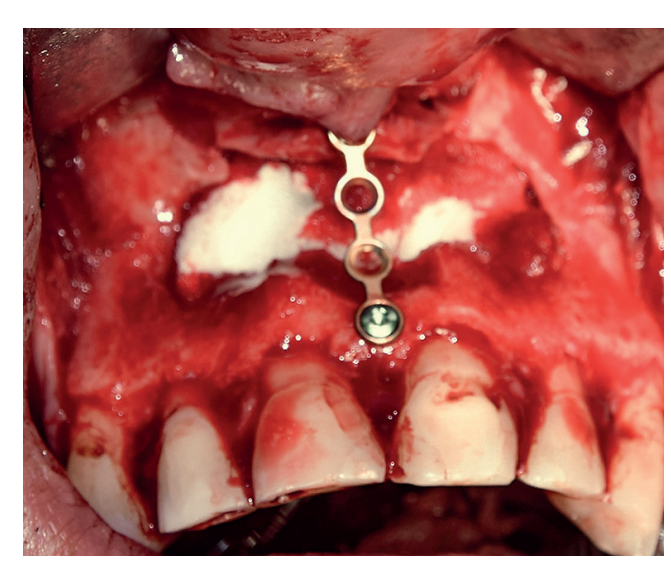

FIGURE 5. Anterior nasal spine adjusted and immobilized with a 1.5 plate fixed with screws 


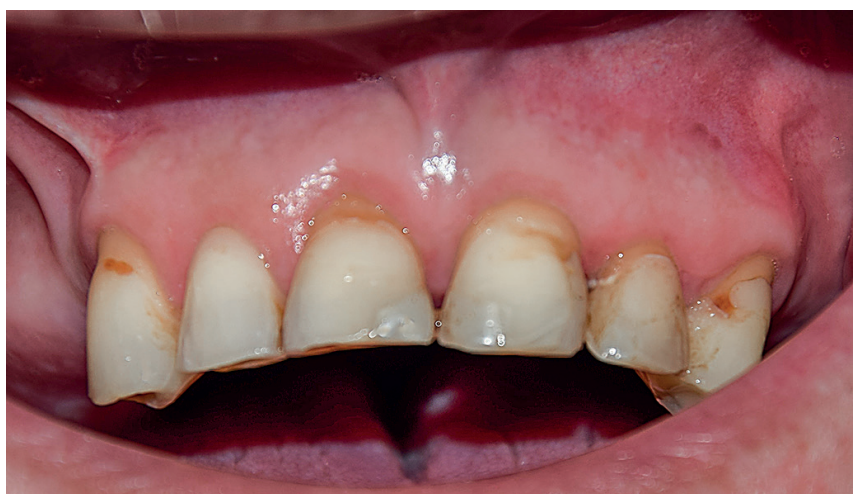

FIGURE 6. Intraoral photo taken 10 months after surgery

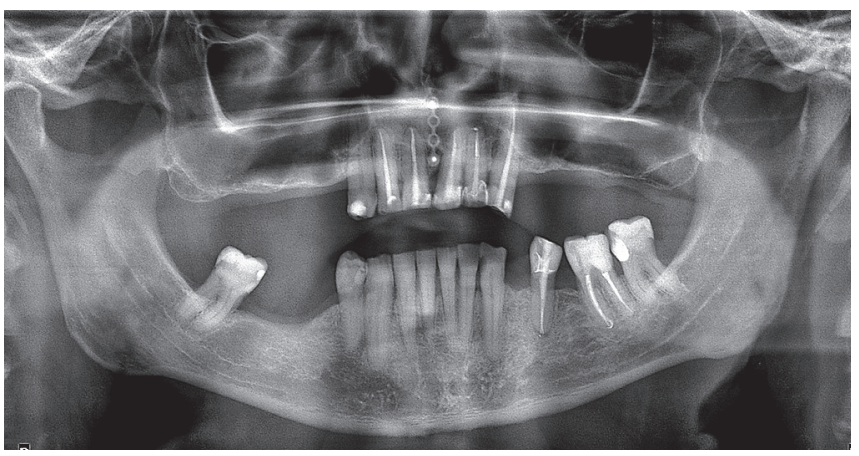

FIGURE 7. Pantomographic X-ray performed 10 months after surgery

\section{DISCUSSION AND REVIEW OF LITERATURE}

In the majority of cases, mesiodentes are diagnosed in children [13], following reports of disorders of permanent teeth eruption, pseudo diastema, rotations and crowding of teeth $[1,2$, $3,5,6,9,10,13]$. In this case, the mesiodens, coexisting with a dentigerous cyst, did not cause any of these abnormalities and it is likely for this reason that it was not diagnosed in childhood. Additionally, the patient had never had any pantomographic X-ray images taken in his life. Slow expansion of the dentigerous cyst caused painless bone atrophy and remained asymptomatic for several decades. In this case, only recurrent inflammatory conditions led to the diagnosis of this pathology. Similar observations were made by Borras-Ferreres et al., who came to the conclusion that dentigerous cysts do not cause clinical symptoms until they are infected or reach large sizes, when they begin to cause of bone deformation, obstruction of tooth eruption, and movement of adjacent teeth [20].

The dominant position in literature regarding the treatment of mesiodentes favours enucleation [18]. However, there are no specific recommendations as to when supernumerary teeth should be removed. In most cases, enucleation is recommended before the expected eruption of permanent incisors [9]. Indications for the enucleation of mesiodentes include: inhibited or delayed eruption of the central incisor, planned orthodontic treatment aimed at changing the position of teeth located in the vicinity of the supernumerary tooth, presence of a mesiodens in patients with cleft lip and palate, as well as in patients in whom implantological treatment is planned in the area of the supernumerary tooth $[1,2]$. Meighani and Pakdaman present two possible approaches: (i) before permanent incisor roots are formed and (ii) after permanent incisor roots are formed. These authors state that it is recommended to remove a mesiodens during the period of early mixed dentition so that the teeth adjacent to mesiodentes can erupt and position themselves properly in the dental arch [5]. The eruption of a tooth adjacent to a mesiodens may occur 6 months to 3 years from the enucleation [21]. In contrast, Shih et al., who conducted research among 384 Taiwanese children with a non-erupted mesiodens, argue that it is reasonable to remove such a tooth before the age of 5 , and the procedure should be performed under general anesthesia. These authors argue that in order to plan the procedure properly before performing surgery, it is necessary to perform an imaging examination using a CT scanner. Such a procedure reduces the risk of complications and makes it possible to avoid orthodontic treatment in the future [22].

If left untreated for too long, mesiodentes may cause disorders of permanent tooth eruption, and thus necessitate interdisciplinary orthodontic and surgical management. Syriac et al. mention the following complications related to the presence of mesiodentes: delay or lack of eruption of permanent teeth, rotations of adjacent teeth, formation of a pseudo diastema, and formation of odontogenic cysts [14]. Mesiodens may also result in the formation of a fused tooth, e.g. presented by Krishnamurthy et al. in the case of a 28 -year-old man with two central incisors fused with a mesiodens [23].

Mesiodens is not only a subject of interest for dentists, but is also sometimes the topic of forensic research. Srivastava et al. examined 8 mesiodens obtained from different individuals and showed that mesiodentes are a good source of DNA and can be useful in forensic medicine for gender identification with PCR [24].

Analysis of the literature on mesiodens shows that apart from clinical trials, mesiodentes are also of interest to researchers in the basic sciences. Tanaskovic-Stankovic et al. studied the content of inorganic components in 26 mesiodentes and 26 normal central incisors. They analyzed the enamel, dentine, and cementum of these teeth, assessing the percentage composition of the most important inorganic components in each part of the teeth. They showed that compared to normal teeth, the enamel and cementum of mesiodentes contained lower levels of calcium and phosphorus, whereas the dentine contained higher level of calcium and lower level of phosphorus. The content of carbon in mesiodens enamel, dentine, and cementum was significantly higher than in normal teeth. Summarizing their research, the authors state that auto- and allotransplantation of mesiodentes is justified because the strength of these teeth is comparable to that of normal teeth [25].

The majority of authors recommend performing CBCT $[9,26]$ before a patient can be qualified for surgery. It allows for detailed, three-dimensional assessment of the location of the mesiodens and, consequently, precise planning of the surgery. Mesiodentes are often in close contact with cortical 
bone lamina [26]. Precise determination of the position of the mesiodens, its relation to the adjacent roots and crowns of permanent teeth, and the location of the incisive canal may help reduce postoperative complications $[9,26]$.

After root cysts, dentigerous cysts are the second most common odontogenic cysts occurring in middle-aged patients $[6,18]$. They are most frequently associated with wisdom teeth in the mandible and maxilla [27]. A distinction is made between developmental and inflammatory dentigerous cysts. In the case described here, the dentigerous cyst reached a significant size. After complete enucleation of the cyst with the supernumerary tooth, a vast bone defect was created, maximum $35 \mathrm{~mm}$ in diameter. As the gap that remained in the bone after the removal of the mesiodens and cyst communicated with the right maxillary sinus, no decision was made to repair the bone defect. The golden standard in bone regeneration is the use of autogenous bone [28]. However, in the regeneration of large bone defects, especially after cystectomies, it can be difficult to obtain the right amount of the patient's bone tissue, and thus alloplastic and xenogenic materials have become a viable alternative in the treatment of such cases [29].

According to many authors, the most effective method is bone regeneration with biomaterial, covering it with a barrier membrane and tight stitching of the wound [30, 31, 32]. The character of the bone defect is an essential determinant of the success of bone reconstruction. Ettl et al. believe that the regeneration of a bone defect with a diameter greater than $30 \mathrm{~mm}$ using xenogenic or synthetic grafts, does not significantly improve the bone regeneration process [16]. It has been proven that there is a correlation between the volume and surface area of the bone defect. In elliptical-shaped cysts located in the mandible, regeneration is faster because these cysts have a larger surface area while maintaining the same volume. Bone defects limited by a thin lamina of compact bone or with one wall of mucous membrane, heal with greater difficulty. This is due to the lack of a spongy substance responsible for blood circulation and the source of extracellular matrix rich in growth factors [29].

In the case described here, the considerable size of the cyst resulted in the fracture and displacement of the anterior nasal spine during enucleation. During the procedure, it was decided to perform repositioning and internal fixation of the broken nasal spine with a Medartis four-eyelet 1.5 plate fixed with 2 screws. The anterior nasal spine is located at the upper end of the intermaxillary suture and is responsible for the appearance of the upper lip and the position of the columella [33]. Therefore, from the point of view of facial aesthetic, in the described case it seems justified to reconstruct the anterior nasal spine.

\section{CONCLUSION}

Dentigerous cysts arising from mesiodentes are rare in adults. Any treatment in such situations should be preceded by computed imaging, preferably CBCT, to confirm the diagnosis and adequately plan the procedure. Treatment of this type of dentigerous cyst consists in the removal of the cyst and the mesiodens.

\section{REFERENCES}

1. Garvey MT, Barry HJ, Blake M. Supernumerary teeth - an overview of classification, diagnosis and management. J Can Dent Assoc 1999;65:612-6.

2. Fernández-Montenegro P, Valmaseda-Castellón E, Berini-Aytés L, GayEscoda C. Retrospective study of 145 supernumerary teeth. Med Oral Patol Oral Cir Bucal 2006;11:339-44.

3. Mahabob MN, Anbuselvan GJ, Kumar BS, Raja S, Kothari S. Prevalence rate of supernumerary teeth among non-syndromic south Indian population: An analysis. J Pharm Bioallied Sci 2012;4:373-5.

4. Olszewski D, Janas A, Grzesiak-Janas G. Ocena rozmiarów i struktury zębów środkowych w materiale Zakładu Chirurgii Stomatologicznej Uniwersytetu Medycznego w Łodzi. Dent Med Probl 2009;46:89-93.

5. Meighani G, Pakdaman A. Diagnosis and management of supernumerary (mesiodens): A review of the literature. J Dent 2010;7:41-9.

6. Khambete N, Kumar R, Risbud M, Kale L, Sodhi S. Dentigerous cyst associated with an impacted mesiodens: report of 2 cases. Imaging Sci Dent 2012;42:255-60.

7. Amini F, Rakhshan V, Jamalzadeh S. Prevalence and pattern of accessory teeth (hyperdontia) in permanent dentition of Iranian orthodontic patients. Iran J Public Health 2013;42:1259-65.

8. Sykaras SN. Mesiodens in primary and permanent dentitions. Report of a case. Oral Surg Oral Med Oral Pathol 1975;39:870-4.

9. Olszewska K, Szczepańska J. Occurence of mesiodens in monozygotic twins - case report. J Stoma 2011;64:612-9.

10. Shah A, Gill DS, Tredwin C, Naini FB. Diagnosis and management of supernumerary teeth. Dent Update 2008;35:510-2.

11. Van der Merwe AE, Steyn M. A report on the high incidence of supernumerary teeth in skeletal remains from a 19 th century mining community from Kimberley. SADJ 2009;64:162-6.

12. Arx T. Anterior maxillary supernumerary teeth: a clinical and radiographic study. Aust Dent J 1992;37:189-95.

13. Grover SB, Singh P, Venkatachalam VP, Hekha N. Mesiodens presenting as a dentigerous cyst: case report. Ind J Radiol Imag 2005;15:69-72.

14. Syriac G, Joseph E, Rupesh S, Philip J, Cherian SA, Mathew J. Prevalence, characteristics, and complications of supernumerary teeth in nonsyndromic pediatric population of South India. J Pharm Bioallied Sci 2017;9: 231-6.

15. Janas A, Grzesiak-Janas G, Ratajek-Gruda M. Mesiodens. Mag Stomatol 2005;15:47-8.

16. Ettl T, Gosau M, Sader R, Reichert TE. Jaw cysts- filling or no filling after enucleation? A review. J Craniomaxillofac Surg 2012;40:485-93.

17. Ko KS, Dover DG, Jordan RC. Bilateral dentigerous cysts - report of an unusual case and review of the literature. J Can Dent Assoc 1999;65:49-51.

18. Reyes JMV, Bermúdez JAE, Ruisánchez YEG. Dentigerous cysts: Case report. J Adv Oral Res 2016;7:41-5.

19. Asaumi JI, Shibata Y, Yanagi Y, Hisatomi M, Matsuzaki H, Konouchi H, et al. Radiographic examination of mesiodens and their associated complications. Dentomaxillofac Radiol 2004;33:125-7.

20. Borras-Ferreres J, Sanchez-Torres A, Aguirre-Urizar JM, Gay-Escoda C. Dentigerous cyst with parietal and intracystic calcifications: a case report and literature review. J Clin Exp Dent 2018;10:296-9.

21. Munns D. Unerupted incisors. Br J Orthod 1981;8:39-42.

22. Shih WY, Hsieh CY, Tsai TP. Clinical evaluation of timing of mesiodens removal. J Chin Med Assoc 2016;79:345-50.

23. Krishnamurthy M, Kumar VN, Leburu A, Jeddy N. Fusion of maxillary central incisors with mesiodens. J Oral Maxillofac Pathol 2018;22:131-4.

24. Srivastava M, Tripathi S, Astekar M, Singal D, Srivastava A, Vashisth P. Sex determination from mesiodens of Indian children by amelogenin gene. J Forensic Dent Sci 2017;9:125-9.

25. Tanaskovic-Stankovic S, Tanaskovic I, Jovicic N, Miletic-Kovacevic M, Kanjevac T, Milosavljevic Z. The mineral content of the hard dental tissue of mesiodens. Biomed Pap Med Fac Univ Palacky Olomouc Czech Repub 2018;162:149-53. 
26. Gurler G, Delilbasi C, Delilbasi E. Investigation of impacted supernumerary teeth: a cone beam computed tomograph (cbct) study. J Istanb Univ Fac Dent 2017;51:18-24.

27. Jain N, Gaur G, Chaturvedy V, Verma A. Dentigerous cyst associated with impacted maxillary premolar: a rare site occurrence and a rare coincidence. Int J Clin Pediatr Dent 2018;11:50-2.

28. Rahnama M, Łobacz M, Czupkałło Ł. Clinical and radiological assessment of the use of Bio-Gen Mix xenografts in jaw bone defects. Pomeranian J Life Sci 2017;63:12-5. doi: 10.21164/pomjlifesci.241.

29. Dominiak M, Łysiak K. Naprawa i/lub regeneracja poresekcyjnych i pocystektomijnych uby tków śródkostnych wyrostka zębodołowego - ocena uwarunkowań na podstawie piśmiennictwa i doświadczeń własnych. Dent Med Probl 2005;42:341-50.
30. Cancian DCJ, Marcantonio RAC, Marcantonio E. Use of BioGran and Cacitite in bone defects: histologic study in monkeys (Cebus apella). Int J Oral Maxillofac Implants 1999;14:859-64.

31. Wychowański P, Urbanowska E, Malec J, Markiewicz H, Wojtowicz A. Inżynieria tkankowa. Cz.2. Ocena wykorzystania autogennej masy płytkowej i Bio-Oss w gojeniu się ubytków kostnych po wyłuszczeniu torbieli żuchwy. Nowa Stomatol 2000;5:23-8.

32. Doblin JM, Salkin LM, Mellado J, Freedman AL, Stein MD. A histologic evaluation of localized ridge augmentation utilising DFDBA in combination with e-PTFE membranes and stainless steel bone pins in humans. Int J Periodontics Restorative Dent 1996;16:120-9.

33. Marianetti TM, Boccieri A, Pascali M. Reshaping of the anterior nasal spine: an important step in rhinoplasty. Plast Reconstr Surg Glob Open 2016;4:1026. 